\title{
Effects of intravenous anesthetic agents on vascular endothelium
}

\author{
Intravenöz anesteziklerin vasküler endotel üzerine etkileri
}

\author{
Alp Gurbet ${ }^{1}$, Fatma Nur Kaya ${ }^{1}$, Alper Bayraktar ${ }^{2}$, Illkin Cavuşoğlu ${ }^{3}$, Serap Şirvancı ${ }^{4}$, Berin Özcan ${ }^{1}$ \\ ${ }^{1}$ Uludağ University Medical Faculty, Dept. Anesthesiology and Reanimation, Bursa, Turkey \\ ${ }^{2}$ Uludağ University Medical Faculty, Dept. Plastic and Reconstructive Surgery, Bursa, Turkey \\ ${ }^{3}$ Uludağ University Medical Faculty, Dept. Histology and Embriology, Bursa, Turkey \\ ${ }^{4}$ Marmara University Medical Faculty, Dept. Histology and Embriology, Istanbul, Turkey
}

\section{ABSTRACT}

Objectives: The objective of this study was to compare the effects of Propofol 1\%, Propofol 2\%, Ketamine, Pentothal, Etomidate and Etomidate-lipuro on venous endothelium.

Materials and methods: The study was done from August 2007 to May 2008 after approval of Faculty's Ethic Committee. Forty rabbits were obtained. Propofol $1 \%(n=6)$, Propofol $2 \%(n=6)$, Ketamin $(n=6)$, Penthotal $(n=6)$, Etomidate $(n=6)$, Etomidate lipuro $(n=6)$ and normal saline (Control Group, $n=4$ ) was given $1 \mathrm{cc}$ via external jugular vein. After 5 minutes from the injenction 6 species $2 \mathrm{~mm}$ in length segments were taken from the injencted veins. Species were fixed in $4^{\circ} \mathrm{C}$ gluteraldehyde than postfixed in $4^{\circ} \mathrm{C}$ osmium tetroxide. Visualisation was performed with scanning electron microscope.

Results: In Propofol $1 \%$, Propofol 2\% and Penthotal groups normal endothelial structures were observed. In Etomidate group damage of the endothelial cells were observed significantly compared with control. In Etomidate lipuro group minimal deformation was observed compared to control.

Conclusion: Etomidat causes significant endothelial deformation, moreover lipuro minimalises these effects. In order to need to use etomidate for general anesthesia, for less pain during injection depending on vascular injury lipuro form would be more appropriate. However, further study is required. J Clin Exp Invest 2011; 3(2): 164-167

Key words: Propofol, ketamine, etomidate, pentothal, etomidate lipuro, vascular damage

\section{INTRODUCTION}

Intravenous (iv) infusions and injections may cause venous complications such as thrombosis or thrombophelibitis in the vein used for infusion. ${ }^{1,2}$ Pain on injection and thrombophelibitis are frequently reported after the administration of benzodiazepines.

\section{ÖZET}

Amaç: Çalışmamızda, genel anestezide kullanılan \%1 Propofol, \%2 Propofol, Ketamin, Pentotal, Etomidat ve Etomidat-Lipuro'nun venöz endotel üzerine olan etkileri karşılaştırılmıştır.

Gereç ve yöntem: Çalışma Fakülte Etik Kurul onayından sonra Ağustos 2007-Mayıs 2008 arasında yapılmıştır. ÇaIışmaya 40 tavşan dahil edildi. Propofol \%1 $(n=6)$, Propofol $\% 2(n=6)$, Ketamin $(n=6)$, Pentotal $(n=6)$, Etomidat $(n=6)$, Etomidat lipuro $(n=6)$ ve salin (Kontrol grubu, $n=4)$ solüsyonlarından 1'er $\mathrm{ml}$ eksternal juguler venden verildi. 5 dakika sonra, enjekte edilen venden $2 \mathrm{~mm}$ uzunlukta 6 'şar kesit alındı. Kesitler $4^{\circ} \mathrm{C}$ gluteraldehid solüsyonunda fikse edilip $4^{\circ} \mathrm{C}$ osmium tetroksid ile yeniden fikse edildi. Kesitler elektron mikroskop ile incelendi.

Bulgular: Propofol \%1, Propofol \%2, Pentotal ve Ketamin gruplarında normal vasküler endotel izlendi. Etomidat grubunda ise kontrol grubuna göre vasküler endotelde anlamlı hasar olduğu görüldü. Etomidat lipuro grubunda ise kontrol grubuna göre minimal deformasyonlar izlendi.

Sonuç: Etomidat vasküler endotelde anlamlı hasar oluştururken lipuro eklenmesi ile bu etkiler azalmaktadır. Genel anestezi için etomidat kullanılacaksa, vasküler hasarın daha az olması ve hastanın enjeksiyon esnasında ağrı duymaması için lipuro formunun tercih edilmesi daha uygun olacaktır. Ancak, bu konuda daha fazla çalışma yapılması gerekmektedir.

Anahtar kelimeler: Propofol, ketamin, etomidat, pentotal, etomidat lipuro, vasküler hasar

Injections of the etomidate have often been associated with pain in the vein used for injection..$^{3,4}$ However, the frequency of reactions differs from one study to another. In our knowledge, there is no study to evaluate the venous complications of 6 different iv anesthetic agents. 
The objective of this study was to compare venous complications of Propofol $1 \%$, Propofol $2 \%$, Ketamine, Pentothal, Etomidate and Etomidatelipuro after venous injection.

\section{MATERIALS AND METHODS}

The study was done in Uludag University Medical Faculty, from August 2007 to January 2008. Fourty rabbits were obtained according to the approval of Uludag University Ethics Committe. After sedatized with im ketamine they cannulated with 24-gauge intravascular catheter via external juguler vein. Propofol $1 \%(n=6)$, Propofol $2 \%(n=6)$, Ketamine $(n=6)$, Penthotal $(n=6)$, Etomidate $(n=6)$ and Etomidate lipuro $(n=6)$ was given $1 \mathrm{cc}$. After 5 minutes from the injenction 6 species $2 \mathrm{~mm}$ in length segments were taken from the injencted veins for every drug and 4 species from uninjected controls. Species were cut longitudinaly and placed on a cork plate endothel faced with the solution. They were fixed in $4^{\circ} \mathrm{C}$ gluteraldehyde $(5 \%, 0.13 \mathrm{M}$ phoshate buffer, $\mathrm{pH}: 7.2)$ for 2 hours than postfixed in $4^{\circ} \mathrm{C}$ osmium tetroxide (1\%, $0.13 \mathrm{M}$ phosphate buffer, $\mathrm{pH}: 7.2)$ for 1 hour and dehydrated in a graded ethanol series; $3 / 1,2 / 2$, $1 / 3$ and pure amylasetat, after drying according to the critical point method with argon (BIO-RAD SC 502) coating with gold palladium. Visualisation and photography was performed with JEOL JSM-5200 scanning electron microscope.

\section{RESULTS}

\section{Control group}

On scanning electron microscopy, all samples were seen to exhibit normal morphological features. Endothelial cells were arranged longitudinally throughout the vascular lumen. The central swelling formed by the nuclei, the spindle-shaped cellular structure, intercellular connections, and the cellular surface appeared to be normal.

\section{P 1\%-Propofol $1 \%$}

The endothelial structure was seen to be intact. There was a decrease in the length of endothelial cells and rounding of the nuclei, while the endothelial surface and intercellular connections were normal. These changes were attributed to the systemic effects of the agent leading to contraction of the vessel wall.

\section{P 2\%- Propofol 2\%}

Generally, the endothelial cells exhibited a normal structure. The anticipated spindle-shape of the endothelial cells could not be demonstrated in some of the samples, while bud-shaped nuclei were observed. There was a loss of tone (relaxation) in the endothelial or muscular layer of vessels was observed. In some regions, minimal separations and detachment of connections between the endothelial cells were observed.

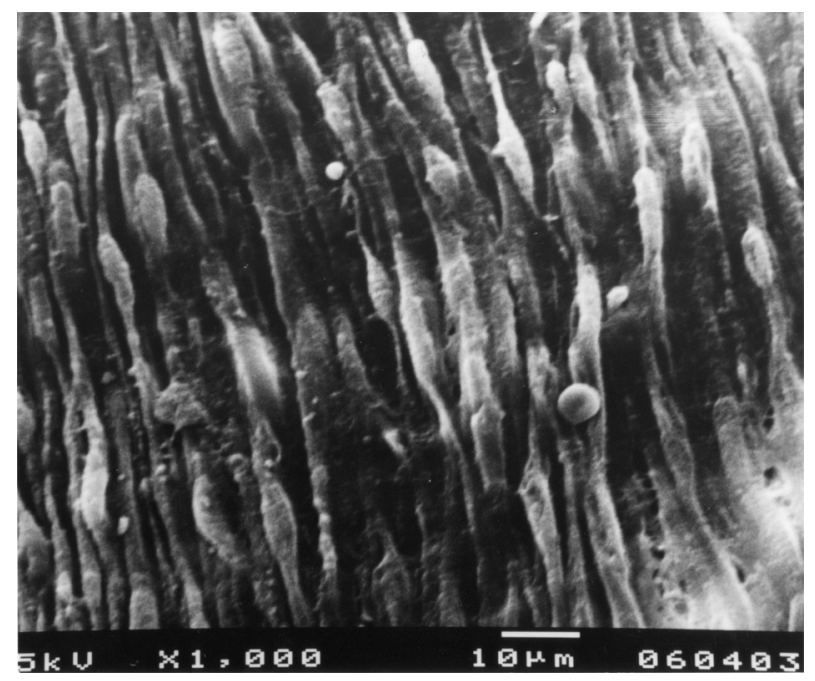

Figure 1. Control

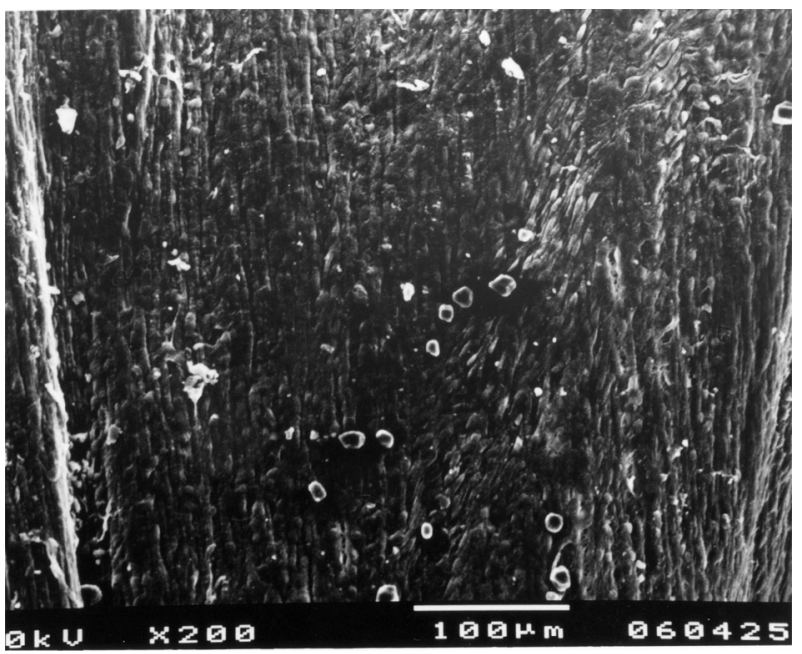

Figure 2. Propofol $1 \%$

\section{P. Penthotal}

Samples numbered 1 and 4 in this group exhibited nearly normal morphology. No disruption was present on the surface of the endothelial cells and between the cells. Relaxation similar to those occurring in the high dose propofol group (P 2\%) was observed. On the other hand, P 2, 3 and 5 samples revealed condensation similar to that occurring in the ketalar group. Irregularity of endothelial cells, changes in the shape of cells, such as becoming dome-shaped and swelling were observed particu- 
larly in the nuclear regions. However, no signs of intercellular detachment, separation or endothelial injury were present.

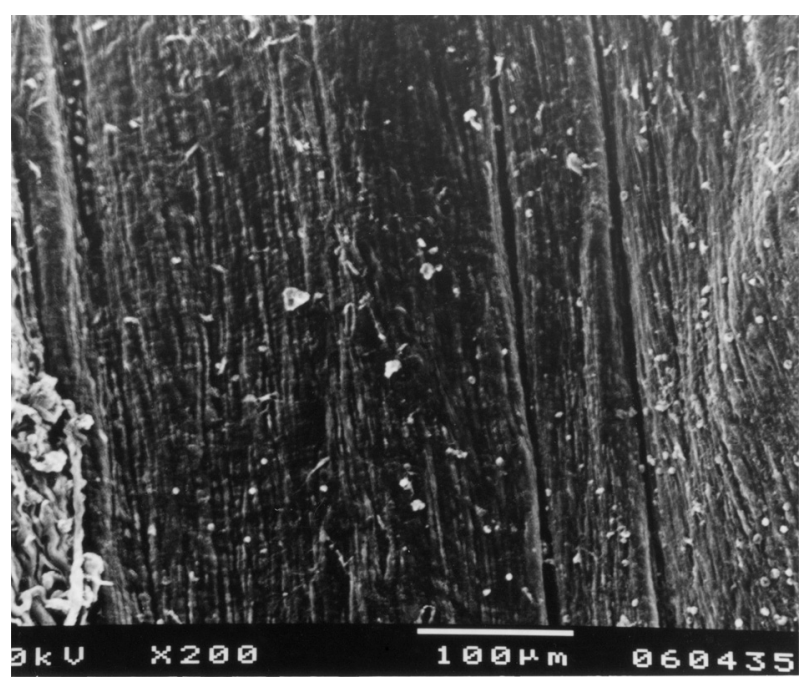

Figure 3. Propofol $2 \%$

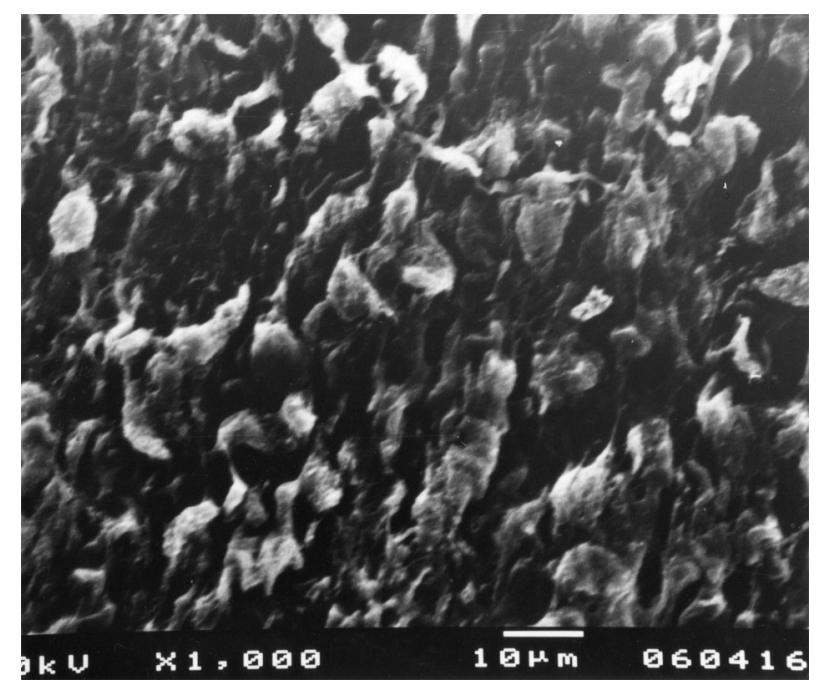

Figure 4. Pentothal

\section{Ke- Ketamine}

Samples in this group did not exhibit any injury on the endothelial surface or any signs of intercellular detachment or breaking away. In general, condensation was seen in the samples. This appearance was considered to have resulted from contraction of the subendothelial muscular layer including the basal membrane. Relatively regular cellular condensation in the sample numbered $\mathrm{Ke} 4$, and irregular compression in the sample numbered $\mathrm{Ke} 6$, were observed.

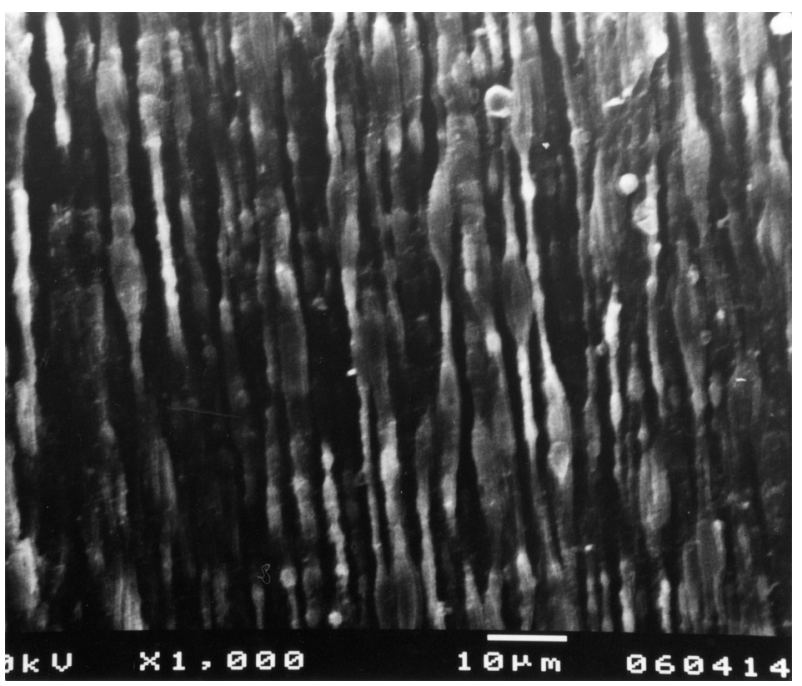

Figure 5. Ketamine

\section{E- Etomidate}

Significant changes were observed in this group. Injuries were prominent at the endothelial surface and between the endothelial cells in all examined samples. Nearly all the samples exhibited detachment and separations in intercellular connections, flattening, swirling and degredation thoroughout the cell surface. These changes which had not been observed in other groups were attributed to the local effects of ethomidate on the endothelial cells located around the injection site.

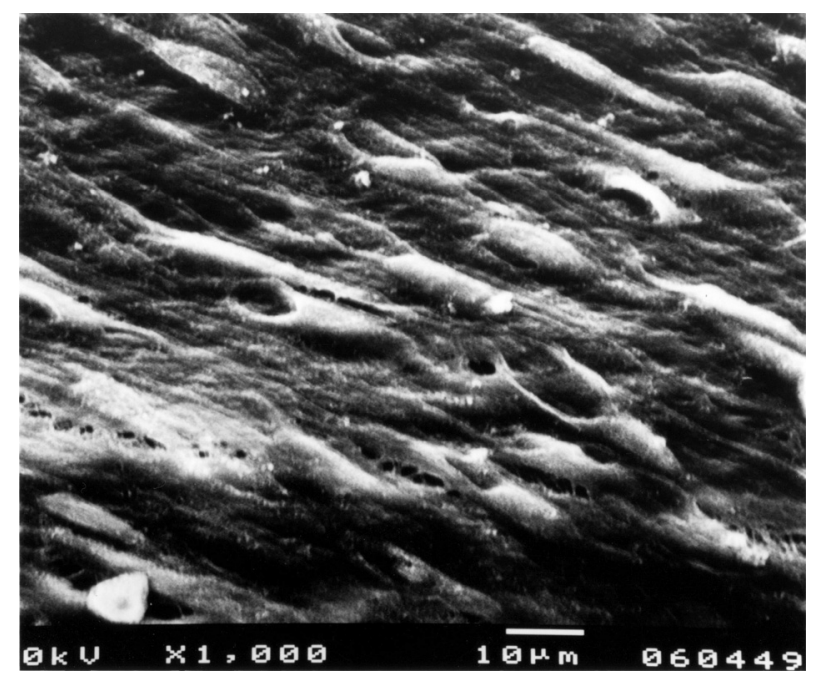

Figure 6. Etomidate

\section{L- Lipuro+Etomidate}

Endothelial injury was minimal in this group and endothelial surface injury which was present in the ethomidate group was not observed. The structure 
of the cells was regular, although minimal detachments among the cells were observed. There was minimal detachment and relaxation among the intercellular connections. Although clustering and irregularity were observed in the $L 7$ sample, no signs of injury were present. Scanning electron microscopy revealed that lipuro significantly decreased the injury effect of ethomidate.

Figure 1 shows the control specimens' photographs. In Propofol $1 \%$, Propofol 2\% and Penthotal group normal endothelial structures were observed (Figures 2, 3, and 4, respectively). Whole cell height was decreased and nucleus was circled. In Ketamine group (Figure 5) no changes in endothelial cell structures were observed. Generally all species were densed. This thought to be stretching of the myofibers with basal membrane. In Etomidate group damage of the endothelial cells were observed significantly compared with control (Figure 6). Cells were disconnected, deformated, flattenned and curved. This thought to be the local injenction effect of the etomidate. In Etomidate lipuro group minimal deformation was observed compared to control (Figure 7). Cells were attached in regular only few cells damaged. Lipuro minimalised the deformation of the cells caused by etomidate visualısed with scanning electrone microscopy.

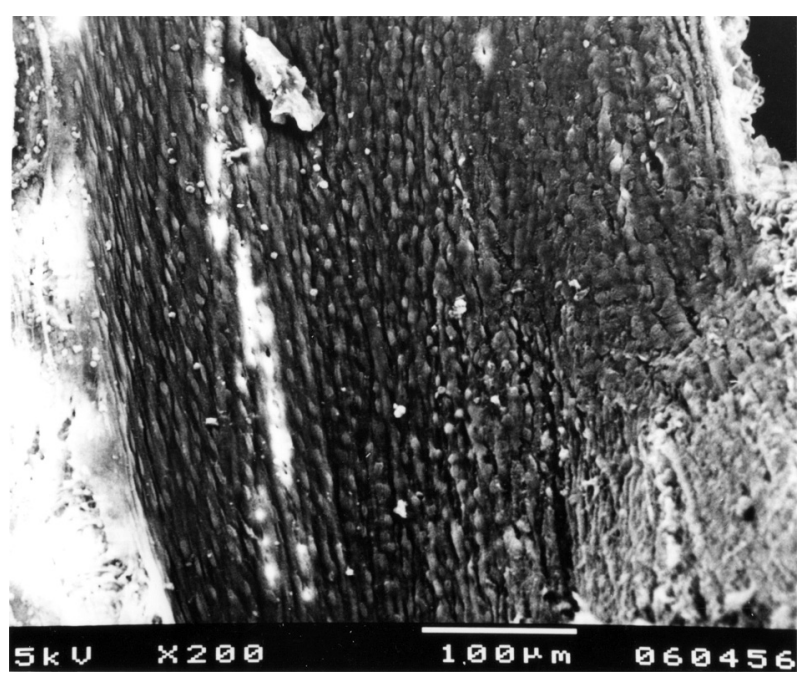

Figure 7. Etomidate Lipuro

\section{DISCUSSION}

The frequency of local venous reactions after iv anesthetics may be related with size of veins, rapidity of injection, solvents and, the time and criteria for defining reactions. ${ }^{5}$ We standardized the size of veins with to use only internal juguler vein, and we did not give any other agents from the same vein.
So, the high incidence of complications after etomidate is most likely to be due to the rug itself, rather than other drugs injected into the same vein. Etomidate is dissolved in propylene glycol that a solvent known to cause pain on injetion and thrombophelibitis. ${ }^{6}$

The incidence of venous complications was $5-9 \%$ after iv injection of thiopentone when assessed by Hewitt et al2 on the second or third postoperative day. But Korttila et $\mathrm{al}^{7}$ were found the incidence of venous sequale much higher than Hewitt et al2, probably due to longer follow-up period (1-2 weeks vs $2-3$ days). Zacharias et al ${ }^{8}$ found a high incidence $(45 \%)$ of venous sequale after rather large doses of etomidate when a 14 day follow-up period. In similar, Korttila et $\mathrm{al}^{7}$ found $43 \%$ incidence of total venous sequale and $16 \%$ incidence of extended thrombophelibitis 14 days after etomidate injection.

We showed that iv anesthethic agents Propofol $1 \%$, Propofol $2 \%$, Ketamin and Penthotal used for general anaesthesia not damaging endothelial cells of the vein and can be used safely. However, Etomidat causes significant endothelial deformation, lipuro minimalises these effects. In conclusion when we need to use etomidate for general anaesthesia we prefer to use etomidate-lipuro.

\section{REFERENCES}

1. Hästbacka J, Tammisto T, Elfving G, Tiitinen P. Infusion thrombophlebitis. A clinical study based upon 1048 cases. Acta Anaesthesiol Scand 1966;10(1):9-30.

2. Hewitt JC, Hamilton RC, O'Donnell JF, Dundee JW. Clinical studies of induction agents. XIV: A comparative study of venous complications following thiopentone, methohexitone and propanidid. $\mathrm{Br} \mathrm{J}$ Anaesth 1966;38(2):115-8.

3. Zacharias M, Clarke RS, Dundee JW, Johnston SB. Evaluation of three preparations of etomidate. $\mathrm{Br} \mathrm{J}$ Anaesth 1978;50(9):925-9.

4. Korttila K, Tammisto T, Aromaa U. Comparison of etomidate in combination with fentanyl or diazepam, with thiopentone as an induction agent for general anaesthesia. Br J Anaesth 1979;51(12):1151-7.

5. Mikkelsen H, Hoel TM, Bryne H, Krohn CD. Local reactions after i.v. injections of diazepam, flunitrazepam and isotonic saline. Br J Anaesth 1980;52(8):817-9.

6. Schou Olesen A, Hüttel MS. Local reactions to i.v. diazepam in three different formulations. $\mathrm{Br} \mathrm{J}$ Anaesth 1980;52(6):609-11.

7. Orttila K, Aromaa U. Venous complications after intravenous injection of diazepam, flunitrazepam, thiopentone and etomidate. Acta Anaesthesiol Scand 1980;24(3):227-30.

8. Acharias M, Clarke RS, Dundee JW, Johnston SB. Venous sequelae following etomidate. $\mathrm{Br} \mathrm{J}$ Anaesth 1979;51(8):779-83. 